Jan W. Żelazny, Niektóre współczesne ośrodki nauki języka syriackiego (Anglia, Włochy, Liban i Indie) (komunikat), [w:] Starożytność chrześcijańska. Materiały zebrane, red. Józef Cezary Kałużny, t. 4, Kraków 2016, s. 247-252.

DOI: http://dx.doi.org/10.15633/9788374385282.16

Jan W. Żelazny

UNIWERSYTET PAPIESKI JANA PAWŁA II W KRAKOWIE

\title{
Niektóre współczesne ośrodki nauki języka syriackiego (Anglia, Włochy, Liban i Indie) (komunikat)
}

Nie jestem filologiem. Stąd myślę, że w związku z tym posiadam wszystkie możliwe wady i zalety związane $z$ dystansem wobec analizowanej podczas dzisiejszego sympozjum działalności pedagogicznej. Jednocześnie swoją przygodę ze szczególnym językiem - językiem syriackim (neologizm, który z większą lub mniejszą skutecznością próbuję propagować w Polsce), rozpocząłem jako starszy pan mający już nie tylko wiele lat życia, ale i doświadczenie płynące zarówno z nauczania specyficznego przedmiotu, jakim jest patrologia, jak i własnych studiów. Patrologia to naprawdę na tym tle przedmiot specyficzny, bo najbardziej znanym źródłem dla uprawiania tej dyscypliny teologii dogmatycznej posługującej się metodą historyczną są teksty ojców Kościoła spisane i zachowane w grece i łacinie, które dla wielu (czytaj - wszystkich, łącznie ze znawcami przedmiotu) są jednocześnie jedynymi liczącymi się świadectwami dotyczącymi rozwoju chrześcijaństwa i jego myśli w starożytności. Jak się okazało, było to założenie błędne, patrologia orientalna zarówno bogactwem tekstów, jak i tłumaczeń z greki i łaciny przewyższa to, co zazwyczaj uważa się za chrześcijańską spuściznę pierwszych wieków.

W toku moich studiów poznawałem język w następujących ośrodkach:

a) PIO w Rzymie, pod kierunkiem profesora Emidio Verganiego,

b) Universitè de Saint-Esprit w Kasliku w Libanie,

c) Klasztorze Mar Chaaya w Broumanie (Liban). 
Jednocześnie spotkałem się ze szkołą w Oxfordzie (poprzez jednego najwybitniejszych specjalistów w tym zakresie, ks. prof. Sebastiana Brocka) oraz w Kerali (Indie) poprzez poznanego w Rzymie ks. Mateusza Potocznego z diecezji opolskiej, z którym kontynuujemy współpracę.

\section{PIO - Rzym}

$\mathrm{Na}$ kurs uczęszczają przede wszystkim studenci z Indii. Dla nich język ten jest językiem liturgii. Jednym $z$ istotniejszych elementów nauki jest kwestia głośnego czytania tekstów. Szczególny problem dla nie-Hindusów to semickie ain. Sam kurs przebiega według oksfordzkiego podręcznika Johna Healeya, podstawą gramatyki jest Louisa Costaza Grammaire syriaque wydane w Bejrucie. Kurs uczy podstawowych koniugacji (tak zwanej koniugacji czasowników mocnych i lomad - youd, jedynie poznaje się pozostałe), a tekstem, który jest tłumaczony, obok czytanek z podręcznika, jest Nowy Testament. Niewątpliwie dla Europejczyka rzeczą ułatwiającą jest wykładowca - Włoch, który w swoich wyjaśnieniach odnosi się do języka łacińskiego. Dla początkującego horrorem jest dyskusja pomiędzy Hindusami a Irakijczykami dotycząca wymowy, a raczej wokalizacji różnych czasowników ${ }^{1}$. W praktyce dla uczącego się podstaw było to trudne i niepotrzebne doświadczenie. Po kursie - sześć miesięcy później - dowiedziałem się, że biegłość wielu uczestników kursu w czytaniu tekstu pochodziła ze znajomości z liturgii na pamięć pewnych sformułowań, a nie z rzeczywistej umiejętności czytania. Być może to także powodowało niekończące się dyskusje. W ramach kursu posługuje się alfabetem serto (choć poznaje się i estrangelo) z zapisem wokalizacji zachodniosyryjskim, choć wzmiankowany jest także system orientalny, kropkowy.

\section{Uniwersytet Ducha Świętego w Kasliku}

Mówiący te słowa miał zamiar uczestniczyć w kursie języka syriackiego w ramach jednego z największych uniwersytetów na Bliskim Wschodzie, w Kasliku, mającego strukturę podobną do opisanego wyżej. Jednak w korespondencji e-mailowej nie poinformowano zainteresowanego o tym, że kurs ten w danym roku się nie odbywał. I tu dotykamy pierwszej

\footnotetext{
1 Dopiero podczas dalszych studiów dowiedziałem się, że to kłótnia na zasadzie: kto ma rację - mówiący gwarą Ślązak czy góral? Choć sama kwestia w języku polskim jest oczywista - wiadomo, Ślązak (w tym wypadku chyba jednak raczej Irakijczycy).
} 
kwestii - napisane, powiedziane a zrealizowane - to trzy różne byty na Bliskim Wschodzie. Kurs nie odbył się, gdyż:

1. Było (i jest) mało studentów - teologię studiuje w całości kilkanaście osób;

2. Wszyscy znają język syriacki z liturgii, choć czytają na podstawie transkrypcji arabskiej, nie do końca rozumiejąc;

3. Studiujący patrologię znają język syriacki najczęściej z domu, czyli pochodzą z małych wspólnot do dziś używających języka syriackiego jako języka macierzystego - nie są zainteresowani kursem podstawowym.

Problemem dla Europejczyka jest grono profesorów i uczniów biegle mówiących, jako jednym z podstawowych dla nich języków, po arabsku. Dla nich problemy z wymową praktycznie nie istnieją (bardziej z akcentem), a wyjaśnienia struktur gramatycznych są robione na podstawie języka arabskiego, którego budowa jest podobna (przez wieki zapisywano teksty arabskie alfabetem syriackim, co samo w sobie pokazuje skalę podobieństwa; nie wspomnę o tym, że większość czasowników ma ten sam trzyliterowy rdzeń, koniugacja i aspekty czynności są te same, podobna jest konstrukcja czasu teraźniejszego).

\section{Mar Chaaya w Broumanie}

Jest to macierzysty klasztor zakonu ojców antonianów - maronitów. Tu mieści się nowicjat, w nim kandydaci do zgromadzenia uczą się języka syriackiego. W ramach powrotu do korzeni jest dość popularne używanie starego aramejskiego w liturgii, zamiast języka arabskiego. Rzadko sprawuje się całą liturgię w języku syriackim, jednak jeśli nie ma wiernych laików we wspólnocie podczas Eucharystii, to większość hymnów i anafor jest syriacka; jeżeli jednak pojawiają się wierni świeccy, zwiększa się udział języka arabskiego. Cześć prowadzących ma predylekcję do jednego, część do drugiego².

Nauczycielem języka, zarówno nowicjuszy, jak i moim, jest Abbuna Emilio al-Habib, wieloletni asystent znanego benedyktyna, prof. Edmunda Becka osB, tłumacza tekstów św. Efrema na język niemiecki, wydawcy w Csco nie tylko tekstów i tłumaczeń syriackich, ale i komentarzy do nich. Abbuna Emil, malfono (tzn. w języku syriackim nauczyciel-mistrz), zna

${ }^{2}$ Nie jest to związane z własną znajomością języka. Abbuna Toni - jeden z wydawców Peszitty interlinearnie z tekstem arabskim - zawsze preferował arabski, choć znał doskonale literacki syriacki i sam czytał swoje czytania po syriacku. Inny z ojców, choć nie znał języka, to się starał... nadrabiając znajomość siłą głosu. 
język syriacki jako język ojczysty - nim posługiwano się w jego domu. W Rzymie, podczas studiów, pracując u Becka, nauczył się podstaw filologii. Dziś pracuje nad tłumaczeniami arabskimi tekstów Jana Dalyaty (wydał już ich część) oraz nad słownikiem syriackio-arabsko-angielskim (może włoskim) dla Europejczyków³.

Ojciec Emil reprezentuje starą szkołę. Należy przeczytać z nim tekst. On pomaga go zwokalizować. Po nauczeniu się tekstu przystępujemy do tłumaczenia, a on, w miarę potrzeb, tłumaczy gramatykę. Razem szuka się słów w słowniku, razem szuka się paralel z innymi językami, starając się odnaleźć myśl autora. Teksty są różne - historyczne, teologiczne, Malfono nie lubi filozofii. To, czego uczy, to z zasady wieloznaczności tekstu, wyczucie czasów w tłumaczeniu (dokonany nie zawsze przeszły, a niedokonany nie zawsze przyszły) etc. Poznanie języka, początkowo chaotyczne, w zależności od tekstu, ugruntowuje się. Szkoła uczy poszukiwania w słowniku, znajomości gramatyki „na wyczucie”, choć podręcznik i paradygmaty są zawsze pod ręką. Uczy jednocześnie wariacji tekstu. Tak nazywam sytuację, gdy zapis z kontekstu różni się od gramatycznej i filologicznej poprawności, choć fonetycznie odpowiada tekstowi. Innymi słowy, patrologa uczula na to, że w tej epoce nie było dobrych korektorów tekstu i jego skład też pozostawiał w manuskryptach wiele do życzenia. System wymaga dużo pracy, konieczności ręcznego przepisywania, płynności w zakresie przechodzenia od wokalizacji do tłumaczenia czy z jednego systemu na drugi. Poznanie dotyczy języka syriackiego $\mathrm{w}$ dialekcie zachodnim używanym przez maronitów w Libanie.

\section{Oxford - Instytut Orientalistyczny}

Na zakończenie chciałem podać kilka uwag dotyczących nauki w Oxfordzie, choć nie jest to ani przekaz osobisty wprost, ani relacja innego studenta, jak to będzie w wypadku Kerali i ks. Mateusza Potocznego.

Będąc w ramach kwerendy w Instytucie Orientalnym, korzystałem z pomocy ks. prof. Sebastiana Brocka. Ponieważ znałem już język, traktował mnie jak swego studenta „zaawansowanego". Dalsze studium języka, o czym chcę wspomnieć, polegało na korekcie błędów popełnianych przez mówiącego te słowa. Rankiem znajdowałem stos książek wraz z sugestią, od czego

\footnotetext{
3 Słownik syriackie są dość trudne, zakładają dobrą znajomość gramatyki i słownictwa u użytkownika. Terminy są bowiem pogrupowane zgodnie z rdzeniami, co przy nieznajomości języka czyni korzystanie z nich bardzo trudnym.
} 
zaczaćc. Zawsze był jeden lub dwa teksty do przetłumaczenia. Jeśli popełniłem błąd, na stoliku pojawiała się pozycja - artykuł - kilka stron ksero ukazujących mi moje braki. Później następowała korekta z mojej strony, czasem w oparciu o coś, co zostało zaznaczone w słowniku przez anonimowego „ktosia”. Po korekcie, jeśli rodzaj błędów się powtórzył, kolejny artykuł z tłumaczeniem filologicznym związanym z moim błędem. Świetne zaawansowane studium, niesamowita dyspozycyjność profesora - chwała mu (choć nie pamiętam, aby ktoś wcześniej zmusił mnie tak do pracy, przy prof. Sebastianie Brocku wszyscy moi nauczyciele byli łagodnymi barankami). Kerala (Indie) - ks. Mateusz pisze:

St. Ephrem Ecumenical Research Institute (SEERI) z siedzibą w Kottayam jest jedyną uczelnią w Indiach, na której nie tylko można studiowaćjęzyk syriacki (yjski), ale także uzyskać państwowy certyfikat jego znajomości firmowany przez Mahatma Ghandi University. Dwuletnie studia kończą się MA z syriackiego (ujskiego), ponadto można robić PhD oraz zwykłe Kursy Certyfikatu.

Podstawę metodologiczną początkowego stadium nauki stanowi wprowadzenie do j. syryjskiego autorstwa prof. S. Brocka. Następnie wprowadzane są kolejno podręczniki i gramatyki autorstwa: G. Kiraza, J. Healeya, W. M. Thackstona.

Plan studiów zakłada naukę gramatyki, syntaksji, fleksji, słownictwa, etc (patrz: załącznik/sylabus). Praktyki studenci nabywają tłumacząc teksty Ojców Syryjskich oraz różnych liturgii wschodniej i zachodniej tradycji syryjskiej. Całokształt studiów moderowany jest przez zespół specjalistów na czele z dyrektorem SEERI, Rev. Dr. Jakobem Thekeparampilem (zob. http:// seeri.org/committee.html) wspomaganym przez szereg profesorów zapraszanych z zagranicy. Egzamin końcowy odbywa się przed komisją państwową powoływaną przez Rząd Stanu Kerala i Uniwersytet MG w коттауAм.

Ja chciałbym dodać, że w relacji powtarza się problem dotyczący specyficznie „innego” podejścia do systematyczności i nauki, z jakim mamy do czynienia na Wschodzie. Zajęcia odbywały się zawsze w zredukowanym wymiarze. Stawiane wymagania raz były wysokie, innym razem - brak wymagań. wyjaśnienia prowadzącego, zdaniem uczącego się, cechował dość duży chaos4.

${ }_{4} \mathrm{Na}$ koniec jedna uwaga - kurs syriackiego to najlepszy znany mi przykład diety wegetariańskiej, prowadzącej do utraty 35 kg wagi ciała przez studenta w ramach cyklu sześcio- 


\section{Podsumowanie}

Myślę, że każdy z poznanych ośrodków proponował coś cennego i godnego uwagi. Najbardziej metodyczne, ale i najbardziej absorbujące dla wykładowcy były zajęcia w Oxfordzie. Ich związek z wykorzystaniem literatury syryjskiej jako źródła do badań patrystycznych i patrologicznych (czyli, używając terminologii niemieckiej, historyczno-teologicznych, bo to właśnie oznacza patrystyka, w odróżnieniu od patrologii) był jasny, a zajęcia prowadzone systematycznie (choć bez oficjalnego kursu, na zasadzie dobrej woli ks. Brocka). Pozwalało to na doskonalenie językowe i poznanie tekstów od strony ich przydatności teologicznej.

Studium języka w krajach Bliskiego Wschodu czy w Indiach pozwala spotkać ludzi, dla których język syriacki nie jest zupełnie martwy, a nawet jest językiem powszednim. Rola native speakers w poznaniu języka jest niewątpliwa, choć metodologicznie zajęciom tym daleko było do systematyczności. Kończąc, powiem tylko, że byłem niespełna rozumu, postanawiając się tym zająć, a zarazem wiem, że nic lepszego zrobić nie mogłem, bowiem spotkanie poprzez ten język ze spuścizną ojców orientalnych zmieniło mnie, dalej mnie zmienia i wydaje mi się, że pozwala zobaczyć takie perspektywy, które zachwycają, bo są po prostu piękne!

miesięcznego, co stanowiło prawie 50\% masy całkowitej. Kursant średnio zadowolony z tego powodu, rodzice zrozpaczeni, ja ks. Mateusza nie poznałem. 